\title{
Complaints and Procedures of Handling Complaints in Financial Institutions of Nepal
}

\author{
Jitendra Prasad Upadhyay, Ph.D. \\ Associate Professor \\ Nepal Commerce Campus, Faculty of Management, T.U.
}

\begin{abstract}
Background - Complaint is a result of dissatisfaction or feeling of injustice/unfair treatment, related to his/her employment situation, which is formally filed and in written form.

Objective - The objective of this paper is to examine the level of complaints that take place in the financial institutions of Nepal. Similarly, this study examines the causes and solutions of complaints in selected financial institutions.

Methodology Used - Descriptive and analytical research designs have been used for the study. Primary data have been collected through the questionnaires using judgmental sampling from the financial institutions of Nepal. Questionnaires have been developed in five scales and mean, standard deviation and coefficient of variation have been used as tools.

Findings - All the financial institutions have faced complaints from their employees and they try to resolve that complaints to their best.

Key words: Complaints; financial institutions; Remedies
\end{abstract}

\section{Background}

A complaint is any type of problem, concern or grievance about work or the work environment. All employees shall be provided a work environment free from sexual, racial, ethnic and religious discrimination/ harassment. Employees, who believe themselves as victims of the discrimination/harassment, start to complain. Employee's complaint is a result of dissatisfaction or feeling of injustice/unfair treatment, either real or imaginary, related to his/her employment situation, which is formally filed and in written form (Griffin, 2000).

\section{Causes of Complaints} as follows;

There may be various factors which cause complaint in an organization (Upadhyay, 2017). They are

a. Low productivity, low motivation, deteriorated product quality/work quality, increased scraps and rejects, indiscipline, unhealthy labour management relation etc.

b. Role of labour union, interpretation differences between management and employee.

c. Supervisory styles, unfair treatment by the management, violation of laws, agreements by management.

d. Sexual, racial, ethnic and religious discrimination/harassment.

\section{Procedures of Handling Complaints (Remedies)}

The top management would appoint at least two complaint managers, one from each gender. The 
Complaint Manager would attempt to resolve complaints by encouraging or inviting employees to walkin any time to express their complaints to higher level management so that matters would be settled immediately by correcting situations or convincing/counseling. If it was not possible to do so then the following procedures would be followed (Upadhyay, 2017).

a) Filing a Complaint: The complaint manager may request the employee to provide a written statement regarding the nature of their complaint. The complaint manger may assist the complainant as needed.

b) Investigation: The complaint manager will investigate the complaint The complaint and identity of the complainant will not be disclosed except (a) as required by law or policy, or (b) as necessary to fully investigate the complaint, or (c) as authorized by the complainant.

The complaint manager will file a written report with the Executive Director of the organizations. If a complaint of harassment contains allegations involving the Executive Director, the written report shall be filed with the Board, which will make a decision in accordance with the policy. The Executive Director will keep the Board informed of all complaints.

c) Decision and Appeal: After receiving the report, the Executive Director's will send his/her written decision to the complainant by mail or through complaint manager. If the employee is not satisfied with the decision, the employee may appeal the decision to the Board by making written request to the complaint manager. Thereafter, the Board will affirm, overrule or modify the decision and render a finding which shall be provided to the complainant.

\section{Financial Institutions (FIs) in Nepal}

A financial institution (FI) is a company engaged in the business of dealing with financial and monetary transactions such as deposits, loans, investments, and currency exchange. Financial institutions encompass a broad range of business operations within the financial services sector including banks, insurance companies, finance companies, and investment dealers. It is an intermediary between consumers and the capital or the debt markets providing banking and investment services.

It is responsible for the supply of money to the market through the transfer of funds from investors to the companies in the form of loans, deposits, and investments.

Development of Nepalese Financial Institutions has a very recent history, starting just from the early twentieth century. In the year 1937 AD, Nepal Bank Limited was established as the first commercial bank in Nepal. In the year 1955, Nepal Rastra Bank Act was formulated for a better banking system and Nepal Rastra Bank (NRB) was established in 1956 as the Central Bank of Nepal. Subsequently, Rastriya Banijya Bank and Agriculture Development Bank (ADBL) were established in 1966 and 1968 respectively.

Till the 1980s, the banking sector was wholly owned by the government, with Agriculture Development Bank, Rastriya Banijya Bank, NBL and NRB being the pillars of financial institutions in Nepal. The entry of other development banks, finance companies, micro-credit development banks, savings and credit cooperatives and Non-government organizations (NGOs) for limited banking transactions started after 1992 under three major acts namely Finance Company Act 1985, Company Act 1964 and Development Bank Act 1996. After introducing these acts, financial institutions in Nepal have seen a steady growth.

As of today, there are 28 commercial banks in Nepal, 33 development banks, 25 finance companies, 65 micro-credit development banks, more than 34,000 cooperatives, 39 insurance companies and 24 NonGovernment Organizations. (NRB Report 2018)

\section{Objectives of the Study}

The main objectives of the study are:

a. To analyze complaints that takes place in the financial institutions in Nepal.

b. To examine the causes and solution of complaints in selected financial institutions in Nepal. 


\section{Methodology Used}

This study has followed both descriptive and analytical approach of research. A questionnaire survey has been conducted for getting the answer of research questions. The questionnaire survey includes 22 questions. Questionnaires were distributed to 25 top, middle and lower level employees of each financial institution. In order to increase the reliability and number of responses, personal visits to each and every respondent were made to distribute and collect the questionnaire. Primary data has been analyzed using the different analytical statistical tools, i.e. the mean, the standard deviation and the coefficient of variance. Total financial institutions in Nepal constitute the population of the study. For this study, only eight financial institutions two from each financial institution i.e. commercial banks, development banks, finance companies and insurance companies have been selected as sample. Selection of sample was based on convenience and judgmental basis.

\begin{tabular}{llll}
\hline \multicolumn{1}{c}{ Commercial Banks } & \multicolumn{1}{c}{ Development Banks } & \multicolumn{1}{c}{ Finance Companies } & \multicolumn{1}{c}{ Insurance Companies } \\
\hline 1. Rastriya Banijya Bank & 1. Kailash Bikash Bank & 1. Manjushree Finance & 1. Rastriya Bima Sansthan \\
Limited (RBBL) & Limited (KBBL) & Company (MFC) & (RBS) \\
$\begin{array}{l}\text { 2. Nabil Bank Limited } \\
\text { (Nabil) }\end{array}$ & 2. Ace Development Bank & 2. Goodwill Finance & 2. Nepal Life Insurance \\
\multicolumn{1}{c}{2} & Limited (SDBL) & Company (GFC) & Company (NLIC) \\
\hline
\end{tabular}

Cronbach's Alpha test has been done to test the reliability of data. Each and every variable have been tested and it was found that every variable reliability test was above $87.69 \%$.

\begin{tabular}{clcc}
\hline S.N. & Details & Total no. of Respondents & Percentage \\
\hline & Institutions & 25 & \\
1 & Rastriya Banijya Bank Limited & 25 & 12.5 \\
2 & Nabil Bank Limited & 25 & 12.5 \\
3 & Kailash Bikash Bank Limited & 25 & 12.5 \\
4 & Ace Development Bank Limited & 25 & 12.5 \\
5 & Manjushree Finance Company & 25 & 12.5 \\
6 & Goodwill Finance Company & 25 & 12.5 \\
7 & Rastriya Bima Sansthan & 25 & 12.5 \\
8 & Nepal Life Insurance Company & 200 & 12.5 \\
& Total & & 100 \\
& Designation & 45 & \\
8 & Top Level & 105 & 22.5 \\
10 & Middle Level & 50 & 52.5 \\
11 & Lower Level & 200 & 25 \\
& Total & & 100 \\
& Age & 60 & \\
12 & Below 30 & 50 & 30 \\
13 & 30 to 40 & 60 & 25 \\
14 & 40 to 50 & 30 & 30 \\
15 & Above 50 & 200 & 15 \\
& Total & & 100 \\
& Gender & 120 & 60 \\
16 & Male & 80 & 40 \\
17 & Female & 200 & 100 \\
& Total & & \\
\hline
\end{tabular}




\section{Respondent's Profile}

This table explains the Respondent's Profile: Institutions Wise, Designation Wise, Age Wise and Gender Wise. Number of respondents in each financial institution was 25. Total respondents are 200 in all financial institutions. Highest number of respondents has been found in Middle Level employee, i.e. 52.5\% or 105 out of 200 and lowest number of respondents has been found in Top Level, i.e. 45 out of 200 or $22.5 \%$. Majority of the respondents have been males, i.e. 120 out of 200 which is $60 \%$ and females have been 80 or $40 \%$. Majority of respondents have been observed in the age below 30 years and between 40 to 50 years which represent 60 each out of 200 respondents. Lowest number of respondents has been in above 50 years group, i.e. 30 or $15 \%$ only.

\section{Analysis and Findings of the Study}

Analysis of different elements of complaints and procedures of handling complaints has been done in this section:

\section{Analysis of Different Elements of Complaints}

\begin{tabular}{lccccccccc}
\hline Name of the financial institutions & PP & WR & PI & MP & OI & Total & Mean & S.D. & C.V \\
\hline Rastriya Banijya Bank Limited & 2.80 & 3.85 & 4.12 & 3.35 & 2.98 & 17.1 & 3.42 & 0.56 & 16.40 \\
Nabil Bank Limited & 2.30 & 3.66 & 3.12 & 3.45 & 2.45 & 14.98 & 3.00 & 0.60 & 20.06 \\
Kailash Bikash Bank Limited & 2.52 & 3.79 & 3.33 & 3.62 & 2.92 & 16.18 & 3.24 & 0.52 & 16.03 \\
Ace Development Bank Limited & 2.21 & 3.89 & 3.45 & 3.33 & 2.75 & 15.63 & 3.13 & 0.65 & 20.92 \\
Manjushree Finance Company & 2.80 & 3.99 & 3.23 & 3.67 & 2.98 & 16.67 & 3.33 & 0.49 & 14.73 \\
Goodwill Finance Company & 2.52 & 3.95 & 3.23 & 3.75 & 2.58 & 16.03 & 3.21 & 0.65 & 20.41 \\
Rastriya Bima Sansthan & 2.68 & 3.97 & 4.18 & 3.29 & 2.79 & 16.91 & 3.38 & 0.68 & 20.02 \\
Nepal Life Insurance Company & 2.72 & 3.86 & 3.18 & 3.65 & 2.88 & 16.29 & 3.26 & 0.49 & 14.99 \\
\hline
\end{tabular}

PP (Personal Problems) explains employee's personal problems. Two questions were asked to the employees in this regard. In all the FIs, the value has been below average, i.e. 3. In case of ACE, it has been the lowest, i.e. 2.21 and in case of RBBL and MFC, it has been the highest i.e. 2.80 compared to others. This indicates that in all the FIs complaint related to personal reasons have not been lodged by the employees.

WR (Work Related) explains work related problems, i.e. motivations, low productivity, indiscipline, products \& work quality, increase in scrap and work environment. Three questions were asked to the employees in this regard. The value of 'WR' in all the FIs has been above average, i.e. 3. Highest value has been observed in case of MFC, i.e. 3.99 and lowest value has been observed in case of Nabil. This shows that work related complaints have been faced by all the FIs. Most of them have problems on working environment of their organizations.

PI (Political Issues) inquires complaints from political motivated labor unions and other political issues. Two questions were asked to the employees in this regard.

In all the FIs, the value of 'PI' has been above average, i.e. 3. Highest value has been found in case of RBS and RBBL i.e. more than 4 and lowest value has been observed in Nabil i.e. 3.12. This shows that all the FIs has faced problem related to political as the values of all the FIs have been more than 3.00.

MP (Management Practices) entails differences between the employees and management due to unclear policies, rules and contract as well as leadership \& supervisory style, unfair treatment with the employees and violations of law \& agreement by management. Three questions were asked to the employees in this regard. The value of 'MP' has been above average in all the FIs. Highest value has been observed in case of GFC, i.e. 3.75 and lowest value has been found in RBS i.e. 3.29. This shows that every FIs, has given more concern to clear its policies, rules and contract among the employees. 
(OI) Others Issues entail sexual, racial, ethnic and religious discriminations and harassment. Three questions were asked to the employees in this regard. The value of 'OI' has been below average in all the FIs, i.e. 3. Highest value has been observed in case of RBBL and MFC, i.e. 2.98 and lowest value has been observed in case of Nabil i.e. 2.45. All the FIs has problems of racial, ethnic and religious discriminations compared to sexual. From the above table, it has been clear that the mean value of "Complaint" in all the FIs has been above average, i.e. 3. This clearly indicates that all the FIs have faced complaints from their employees. Political Issues have been seen in government organization i.e. in RBBL and RBS compared to private organizations. In all the cases, the value of standard deviation has been below 1 and coefficient of variation has been $14.73 \%$ to $20.92 \%$, which indicates that the average was more representative across the FIs as well as across the different components of complaint.

\section{Analysis of Different Elements of Remedies}

\begin{tabular}{lcccccccc}
\hline Name of the Public Enterprises & SM & CM & BD & FP & Total & Mean & S.D. & C.V \\
\hline Rastriya Banijya Bank Limited & 3.75 & 2.65 & 4.03 & 4.45 & 14.88 & 3.72 & 0.77 & 20.67 \\
Nabil Bank Limited & 3.98 & 2.66 & 3.98 & 4.18 & 14.80 & 3.70 & 0.70 & 18.91 \\
Kailash Bikash Bank Limited & 3.69 & 2.98 & 3.97 & 4.17 & 14.81 & 3.70 & 0.52 & 14.05 \\
Ace Development Bank Limited & 3.85 & 2.95 & 4.01 & 4.21 & 15.02 & 3.76 & 0.56 & 14.82 \\
Manjushree Finance Company & 3.98 & 2.76 & 4.05 & 4.35 & 15.14 & 3.79 & 0.70 & 18.54 \\
Goodwill Finance Company & 3.92 & 2.87 & 4.06 & 4.16 & 15.01 & 3.75 & 0.60 & 15.90 \\
Rastriya Bima Sansthan & 3.95 & 2.91 & 3.98 & 4.28 & 15.12 & 3.78 & 0.56 & 15.84 \\
Nepal Life Insurance Company & 3.85 & 2.58 & 3.98 & 4.18 & 14.59 & 3.65 & 0.72 & 19.86 \\
\hline
\end{tabular}

SM (Special Measures) has been concerned about special measures taken by the management to handle complaints. Two questions were asked to the employees in this regard. The value of 'SM' has been above average in all the FIs i.e. 3. Highest value has been found in Nabil and MFC, i.e. 3.98 and lowest value has been seen in RBBL, i.e. 3.75. This indicates that every FIs has been more concerned about handling any kind of complaints.

CM (Complaint Manager) explains appointing complaint manager to resolve the complaints. Two questions were asked to the employees in this regard.

In all the FIs, the value of ' $\mathrm{CM}$ ' has been below average, i.e. 3. In case of KBBL, it has been highest i.e. 2.98 whereas in NLIC it has been 2.58 lowest. This shows that every FIs has not appoints complaint managers to resolve the complaints.

BD (Bilateral Dialogue) is concerned with bilateral dialogue with the concerned people. Two questions were asked to the employees in this regard.

This value has been higher than the average in all the FIs, i.e. 3. Individually, GFC showed good by scoring 4.06. In case of KBBL, it has been 3.97 lowest. This shows that all the FIs have put its effort to resolve the problems by a bilateral dialogue.

FP (Following Procedure) has been made to resolve the complaint by following certain procedure, i.e. filing a complaints, investigations and decision $\&$ appeal. Three questions were asked to the employees in this regard. In all the FIs, the value of 'FP' has not only been above average, i.e. 3 but it is above 4 . In case of RBBL, it has been the highest, i.e. 4.45 and in case of GFC, it has been the lowest, i.e. 4.16. This shows that all the FIs have been using procedures like, filing a complaint, investigation and at last decision will be given to resolve the complaints.

From the above table, it has been observed that mean value of 'Remedies' in all the FIs has been above average, i.e. 3. Highest value has been found in MFC, i.e. 3.79 and lowest value has been observed in NLIC, i.e. 3.65. This indicates that all the FIs has been using this approach to resolve the complaints of the 
employees. In all the cases, the value of standard deviation has been below 1 and coefficient of variation has been $14.05 \%$ to $20.67 \%$, which indicates that the mean calculated has been representative across different FIs and across different components of 'Remedies' and hence mean is trustworthy.

\section{Conclusions}

Complaint is an employee's dissatisfaction or feeling of injustice/unfair treatment, either real or imaginary, related to his/her employment situation. It arise due to lack of communication, unfair pay, no job security, lack of appreciations, nepotisms \& favoritisms, work overload, incompetent leader, sexual \& religious harassment $\&$ discriminations and lack of opportunity etc. Remedies are the attempt to resolve complaints by encouraging or inviting employees to express their complaints to the management so that matters will be settled immediately by correcting situations or convincing/counseling.

All the Financial Institutions have faced complaints from their employees and they try to resolve that complaints to their best. Thus, it can be said that all the Financial Institutions seem to have faced and used the CR approach in their banks. Standard deviation and coefficient of variation of all the Financial Institutions were low indicating mean has been much trustworthy. Most of the public enterprises have faced political, work related and management problems compared to personal.

\section{References}

Anthony, R. \& Govindarajan, V. (1998), Management Control System Mc-Graw Hill. Banking and Financial Statistic of Nepal Rastra Bank, 2018

Bromwich, M. (1990). "The case for Strategic Management Accounting: The Role of Accounting Information for Strategy in competitive Markets, ” Accounting, Organization and Society. No. 1.

Economic Survey (2017-18), Government of Nepal, Ministry of Finance, 2018

Griffin, W. (2000). Management. AITBS Publishers and Distributors, Delhi.

Ivancevich, M., Donnelly, H. \& Gribson, L.(2001). Management: Principles and Functions. AITBS

Publishers and Distributors. Delhi.

Jawahar Lal. (2003). Advanced Management Accounting, Text and Cases. S. Chand \& Company Ltd., New Delhi.

Kaplan, S. \& Atkinson, A. (2005). Advanced Management Accounting. Prentice Hall of India Pvt. Ltd., New Delhi.

Kenneth, A. (2002). Modern Management Control Systems. Text \& Cases. Pearson Education, Asia.

Kunreuther, H.C., Pouly, M. V. \& Mc Merrow, S. (2012). Insurance and Behavioral Economics Improving Decisions in the Most Misunderstood Industry.

Lere, C. \& Portz, K. (2005). Management control systems in a Global Economy. Pearson Education, Asia. Levine, Krehbiel \& Berenson. (2004). Business Statistics, A first course. Pearson Education, Asia.

Manandhar, N. (1988). Public Enterprises and Privatization. Ministry of Finance, Government of Nepal, Kathmandu Nepal

Narayan, L. (2000). Principles and Practice of Public Enterprise Management. Sultan Chand and Company Limited, New Delhi.

Robbins, S. \& Coulter, M. (2000). Management. Prentice Hall of India Pvt. Ltd., New Delhi.

Shekhar, C. and Shekhar, L. (2000). Banking Theory and Practice. Vikash Publication Pvt. Ltd., New Delhi.

Wolff, K. \& Pant, R. (2005). Social Science Research and Thesis writing. Buddha Academic Publishers and Distributors Pvt. Ltd., Kathmandu, Nepal.

Upadhyay. J. P. (2017), Complaint and Procedures of Handling Compalints in Public Enterprises of Nepal. GE-International Journal of Management Research (AARF). 